\title{
Symposium review: Big data, big predictions: Utilizing milk Fourier-transform infrared and genomics to improve hyperketonemia management*
}

\author{
R. S. Pralle $\bullet$ and H. M. White† $\odot$ \\ Department of Dairy Science, University of Wisconsin-Madison 53706
}

\begin{abstract}
Negative animal health and performance outcomes are associated with disease incidences that can be labor-intensive, costly, and cumbersome for many farms. Amelioration of unfavorable outcomes through early detection and treatment of disease has emphasized the value of improving health monitoring. Although the value is recognized, detecting hyperketonemia (HYK) is still difficult for many farms to do practically and efficiently. Increasing data streams available to farms presents opportunities to use data to better monitor cow and herd health; however, challenges remain with regard to validating, integrating, and interpreting data. During the transition to lactation period, useful data are presented in the form of milk production and composition, milk Fourier-transform infrared (FTIR) wavelength absorbance, cow management records, and genomics, which have been employed to monitor postpartum onset of HYK. Attempts to predict postpartum HYK from test-day milk and performance variables incorporated into multiple linear regression models have demonstrated sufficient accuracy to monitor monthly herd prevalence; however, they lacked the sensitivity and specificity for individual cow diagnostics. Subsequent artificial neural network prediction models employing FTIR data and milk composition variables achieved 83 and $81 \%$ sensitivity and specificity for individual cow diagnostics. Although these results fail to reach the diagnostic goals of $90 \%$, they are achieved without individual cow blood samples, which may justify acceptance of lower performance. The caveat is that these models depend on milk analysis, which is traditionally done every 4 weeks. This infrequent sampling allows for a single diagnostic sample for about half of the fresh cows. Benefits to farms are greatly improved if postpartum cows can be milk-tested weekly. Additionally, this allows for close monitoring of somatic cell count and
\end{abstract}

Received August 1, 2019.

Accepted November 14, 2019.

*Presented as part of the Production, Management, and the Environment Symposium: Advancing Artificial Intelligence on Dairy Farms at the ADSA Annual Meeting, Cincinnati, Ohio, June 2019. †Corresponding author: heather.white@wisc.edu may open the door for use of other herd health monitoring tools. Future improvements in these models may be achievable by maximizing sensitivity at the expense of specificity and may be most economical in disorders for which the cost of treatment is less than that of mistreating (e.g., HYK). Genomic predictions for HYK may be improved by incorporating genome-wide associated SNP and further utilized for precision management of HYK risk groups. Development and validation of HYK prediction models may provide producers with individual cow and herd-level management tools.

Key words: ketosis, herd health, Fourier-transform infrared, transition cow

\section{INTRODUCTION}

Advances in dairy cattle management, nutrition, genetics, and reproduction not only represent improvements in knowledge of dairy cattle biology but are reflective of availability and timeliness of data. Routine analysis of milk samples started as a way to monitor milk fat and protein and has progressed to other complex traits and monitoring of herd health indicators. Other data are now available to farms from numerous sources, including feeding systems, rumination sensors, activity monitors, robotic milking systems, and weather stations, to name a few (Wathes et al., 2008; Wolfert et al., 2017). Furthermore, management systems incorporating advanced technology can be accessed by off-farm management team members and can send real-time alerts.

Although undoubtedly a wealth of knowledge and potential exists in the pool of data from the aforementioned systems, a great need remains to sort, validate, and integrate these data into forms that are userfriendly, consistent across platforms and manufacturers, and practically applicable. For many research teams, an obvious place to start has been with detection of health events or monitoring of high-risk physiological periods. Development of individual diagnostic and herd-level management tools for these disorders can yield economic, production, and animal health benefits. Of particular interest to us and others is monitoring animal health during the transition to lactation period. This is 
a period of increased risk for metabolic disorders such as hyperketonemia (HYK), hypocalcemia, and fatty liver. The purpose of this review is to recognize the progress that has been made, as well as highlight future opportunities, in using "big data" to monitor herd health, specifically with regard to HYK.

\section{HYPERKETONEMIA PREDICTION FROM MILK AND MANAGEMENT DATA}

The reference test for HYK diagnosis is the quantification of blood serum or plasma BHB concentration via enzymatic assay (Iwersen et al., 2009; McArt et al., 2013). The establishment of current blood or blood fraction BHB thresholds based on the increased risk of unfavorable animal health and performance outcomes has been thoroughly reviewed (McArt et al., 2013; Overton et al., 2017), with thresholds of BHB $\geq 1.2$ $\mathrm{mmol} / \mathrm{L}$ and $\mathrm{BHB} \geq 1.4 \mathrm{mmol} / \mathrm{L}$ being the most frequently used. Although evidence suggests that dietary and management factors affect basal blood BHB concentration (DeFrain et al., 2006; Roche et al., 2010), $\mathrm{BHB} \geq 1.2 \mathrm{mmol} / \mathrm{L}$ has been suggested as a universal standard for HYK diagnosis (Suthar et al., 2013).

Despite the availability of handheld BHB meters that can be used cowside, diagnostic protocols based on blood BHB are costly and labor-intensive, presenting application challenges (McArt et al., 2014; Denis-Robichaud et al., 2014; Sailer et al., 2018). Alternatively, collection of a milk sample is noninvasive and can be incorporated into milking routines, and concentrations of milk ketone bodies are correlated with their blood concentrations (Marstorp et al., 1983; Andersson, 1984; Denis-Robichaud et al., 2014). Fourier-transform infrared (FTIR) spectrometry has provided a practical method of predicting milk ketone body concentrations, and although it is not currently as accurate as chemical quantification of the molecules using gas-liquid chromatography, flow injection analysis, or enzymatic assays, it can be implemented on a larger scale, given that it is already used for routine DHI milk testing (de Roos et al., 2007). Furthermore, predicted concentrations of milk acetone or BHB from FTIR correlate $(\mathrm{r}=0.80)$ with chemically analyzed milk concentrations (de Roos et al., 2007).

Attempts to evaluate the efficacy of milk ketone body concentrations for HYK diagnosis have been challenged in the establishment of diagnostic thresholds. A range of milk BHB and acetone thresholds have been suggested based on concordance with blood or blood fraction BHB diagnosis. Enjalbert et al. (2001) suggested thresholds of milk acetone, as determined via gas-liquid chromatography, of $\geq 160 \mu \mathrm{mol} / \mathrm{L}$ and enzymatically determined milk $\mathrm{BHB} \geq 70 \mu \mathrm{mol} / \mathrm{L}$ for sensitive (91.7\%) HYK screening; however, accuracy was low at $64.0 \%$ and $69.4 \%$ for milk acetone and milk BHB, respectively. Similar thresholds were determined by van der Drift et al. (2012b) using FTIR-predicted milk acetone $(131.5 \mu \mathrm{mol} / \mathrm{L})$ and milk BHB (76.3 $\mu \mathrm{mol} / \mathrm{L})$, with accuracies of 87.1 and $76.8 \%$, respectively. Conversely, van Knegsel et al. (2010) reported that much lower thresholds of FTIR-predicted milk acetone of $\geq 70 \mu \mathrm{mol} / \mathrm{L}$ and milk BHB of $\geq 23 \mu \mathrm{mol} / \mathrm{L}$ maximized accuracy of HYK diagnosis, 71.6 and $70.7 \%$, respectively. Comparison of FTIR-predicted milk BHB ( $\geq 1.2 \mathrm{mmol} / \mathrm{L}$ as the diagnostic threshold) with blood BHB resulted in overall sensitivity and specificity of 81 and 92\%, respectively (Renaud et al., 2019). Similar sensitivity and specificity were achieved when FTIR-predicted BHB and acetone were analyzed in primiparous, but not multiparous, Holstein and Jersey cows (Chandler et al., 2018). Additional incorporation of performance variables including dry period length, gestation length, and lactation number to milk analysis results (fat, protein, FTIR-predicted acetone and BHB) improved accuracy of models to predict HYK but still lacked the sensitivity to provide an individual cow diagnostic tool (Chandler et al., 2018). Regardless of the lack of sensitivity of these models compared with enzymatic blood BHB quantification, a role remains for these models in herd-level diagnostics and monitoring (Denis-Robichaud et al., 2014; Chandler et al., 2015). Routine (i.e., monthly) implementation of these herdlevel HYK predictions can aid farms in monitoring prevalence and identifying patterns and farm-specific risk factors. Additional benefits may derive from observing herd health consequences from intentional or unintentional management and environment changes.

Efforts to increase reliability of model predictions have involved the use of more advanced statistical modeling techniques, larger sample sets, and raw FTIR wavelength data. Using a data set of more than 3,600 samples (divided into training and external testing sample sets), artificial neural network models based on milk analysis (such as milk fat, protein, FTIR-predicted acetone and BHB), and raw FTIR wavelengths resulted in improved HYK prediction models compared with models using either FTIR data or milk analysis data alone, or models built using multiple linear or partial least squares regression (Pralle et al., 2018). Despite failing to reach the diagnostic accuracy of cowside enzymatic blood tests such as the Precision Xtra (Abbott Diabetes Care, Alameda, CA) and BHBCheck (PortaCheck, Moorestown, NJ) meters (Iwersen et al., 2009; Sailer et al., 2018), these models are considered to have "very good" diagnostic capacity based on general thresholds of diagnostic accuracy (Šimundić, 2009). When we recall that the goal of using FTIR milk analy- 
sis to diagnose HYK was to reduce the cost and labor necessary to employ blood-based diagnostics on farm, we may be willing to accept slightly lower diagnostic capacity in exchange for the reduced intensity and cost of FTIR-based diagnostics (Pralle et al., 2018). A positive case of HYK is likely to be treated with oral propylene glycol, a low-cost treatment that requires no milk withdrawal (McArt et al., 2012a, 2014), resulting in minimal consequence to treating a false-positive case. Given this, an opportunity may exist to maximize prediction model sensitivity, at the expense of specificity, while maintaining cost-effectiveness and promoting animal welfare.

\section{GENETIC AND GENOMIC MANAGEMENT OF KETOSIS}

Investigations into genetic selection for HYK susceptibility have predominately relied on voluntary records provided by dairy producers. Threshold model heritability estimates have ranged from 0.02 to 0.17 in Holstein cows (Kadarmideen et al., 2000; Zwald et al., 2004; Parker Gaddis et al., 2014; Klein et al., 2019). Presently, Zoetis Genetics (Kalamazoo, MI) is the only provider of genomic evaluations for HYK susceptibility, which is marketed as ketosis resistance, based on voluntary records in the United States (Vukasinovic et al., 2017); however, misclassification of HYK cases as controls (or as nonevents) is a problem with voluntary records, especially when considering subclinical cases and the variation in HYK diagnosis criteria (Oetzel, 2004; Pryce et al., 2016). Weigel et al. (2017) explored the heritability of HYK based on intensive sampling of blood BHB concentration at 4 time points between 5 and 18 DIM (inclusive), and the estimated heritability for the binary assignment of HYK was 0.07 , which was within the range reported for voluntary records. The authors were unable to evaluate the effectiveness of voluntary records as an indicator of an intensively sampled HYK phenotype because farm managers were not blind to HYK assessment. Nonetheless, it was proposed that a reference population of cows could be established for population-wide genomic predictions of HYK susceptibility (Weigel et al., 2017).

Milk ketone body concentration, predicted from FTIR and collected during routine DHI testing, has been proposed as an indicator trait for HYK susceptibility. These traits are heritable, with milk acetone heritability ranging from 0.10 to 0.28 (van der Drift et al., 2012a; Ranaraja et al., 2018) and milk BHB heritability ranging from 0.067 to 0.19 (van der Drift et al., 2012a; Koeck et al., 2014; Jamrozik et al., 2016; Ranaraja et al., 2018). Genetic correlations between clinical HYK records and FTIR-predicted ketone bod- ies are moderate, ranging from 0.25 to 0.48 (Koeck et al., 2014; Jamrozik et al., 2016). Although these results suggest that FTIR-predicted milk ketone bodies are promising HYK indicator traits, the correlation between these test-day milk BHB or acetone traits and the more intensively sampled HYK phenotypes has not been explored. Further investigation into these associations will inform on the adequacy of monthly milk ketone body concentration records as the basis for genomic management strategies of subclinical HYK susceptibility.

Incorporation of genetic and genomic evaluations of HYK susceptibility into management through animal breeding programs is intuitive. A potential concern for directly breeding against HYK susceptibility is the unintentional elimination of compensatory metabolism (i.e., ketogenesis), at least with respect to the subclinical phenotype. Use of genomics as a tool for precision health management is a largely unexplored alternative. Genome-guided management of HYK would be like personalized medicine, where estimated breeding values for HYK, alone or coupled with other on-farm data streams such as test-day prediction models (Chandler et al., 2018; Pralle et al., 2018), could be used to stratify cows into risk groups for group-specific management (Weigel et al., 2017).

The scheme we propose is based on polygenic risk, because complex traits reflect numerous small effects from loci across the genome. A subset of SNP may explain an effective amount of variance that can augment HYK management. Indeed, Nani et al. (2019) found that genomic predictions incorporating a subset of genome-wide significant SNP considerably improved the predictive ability of whole-genome models for sire conception rate. Therefore, genome-wide association studies (GWAS) for HYK may indicate a subset of SNP worthy of increased weighting in genomic evaluation of HYK susceptibility [e.g., weighted genomic best linear unbiased prediction (GBLUP)]. Previous GWAS for HYK based on voluntary records have not identified SNP with genome-wide significant associations (Parker Gaddis et al., 2018; Klein et al., 2019). We believe the present lack of genome-wide associations is due to voluntary record HYK phenotypes having variation in trait definition across herds (i.e., subclinical vs. clinical, urine vs. blood ketone body metrics) and having high misclassification rates caused by insufficient assessment frequency (i.e., only 1 blood BHB measurement within the first 21 DIM). A preliminary GWAS in Holstein cows, specifically for a subclinical HYK phenotype based on multiple blood BHB measurements, has marginal genome-wide evidence for a single SNP association and significant evidence for SNP associations dependent on parity status (Pralle et al., 2019 a,b). 
Further validation of these findings would justify use of specific SNP genotypes for HYK risk assessment, potentially in a parity-dependent manner.

\section{ON-FARM INTEGRATION OF HERD-HEALTH DIAGNOSTICS, CHALLENGES, AND OPPORTUNITIES}

Although the collective body of research has generated diagnostic tools, on-farm integration and implementation remain difficult. A few key challenges present hurdles and deserve our vested interest. Here we address 4 that appear to be limiting progress at this point: the nature of "monthly" DHI milk testing on farm, differences in proprietary FTIR predictions across FTIR equipment manufacturers, challenges in implementing advanced computational models and integrating data streams for farm usability, and validation of the accuracy of prediction models within experiments and across dairy operations.

Historically, DHI milk sampling has been performed about every 4 weeks on privately owned dairy farms (Weigel et al., 2017). Based on the at-risk period and duration for HYK, a farm would test only half of the fresh cows during the peak risk period (3 to 18 DIM; McArt et al. 2012b), and those cows would be tested only once. The 2 intuitive ways to address this challenge are (1) to produce equations based on in-line measurement systems and (2) to implement weekly milk testing of fresh cows. Current in-line systems include Herd Navigator (DeLaval International AB, Tumba, Sweden) and AfiLab (Afimilk, Kibbutz Afikim, Israel); however, only the former provides milk BHB predictions for monitoring HYK (Blom et al., 2015). For farms that do not have in-line measurement systems, the second option could be viable. In this system, all early-postpartum cows would be milk sampled weekly, resulting in fresh cows being sampled twice during the at-risk period. Use of prediction models on these samples would allow for either treatment of cows predicted positive or generation of a list of cows that warrant blood BHB testing. Beyond detection of HYK, these weekly milk samples could have additional benefits. Reporting SCC or differential SCC could provide valuable information in this postpartum period, to help identify cases of mastitis earlier (Fourdraine et al., 2019). As the technology continues to improve (e.g., differential SCC), it may also be a means to flag cows with increased inflammatory markers. Furthermore, if a group of cows are being milk tested weekly, it is not beyond reason that other subgroups would be selectively milk sampled that day, which opens the door further for using milk FTIR to determine energy balance (McParland et al., 2015;
Grelet et al., 2016), evaluate likelihood of conception (Ho et al., 2019), test for pregnancy in mid-lactation cows (Lainé et al., 2017; Toledo-Alvarado et al., 2018), or monitor cows within treatment pens. Milk analysis does not occur without cost, but analysis from postpartum cows may provide more valuable information than analysis from cows in late lactation, allowing us to envision that DHI programs of the future may shift to more frequent testing of cows in periods of interest.

The second challenge, differences in FTIR equipment and proprietary predictions across manufacturers, is apparent to collaborative research teams when working across DHI organizations or trying to reconcile compiled results as discrepancies arise throughout growing data sets. Although the equipment is based on the same technology, standards are still primarily used for controlling the basic components (e.g., fat, protein) across the industry. Given the proprietary nature of the predictions offered by companies, we may not be able to compare FTIR-predicted characteristics (such as short-chain fatty acids) across manufacturers. Furthermore, these proprietary predictions change over time, even within a manufacturer. Standardization efforts can reduce background noise and prediction errors and are sensitive to milk composition shifts (Tiplady et al., 2019). These differences may not be as evident to producers viewing results from a single DHI laboratory, but if research is based on separate platforms, there may be limitations to on-farm application based on the equipment used by the DHI or in-line system.

As discussed herein, prediction of complex metabolic disorders will likely have marginal improvements in precision and accuracy when utilizing computationally advanced methods, such as artificial neural networks. Appreciable gains in model performance were observed when incorporating more data from several sources (i.e., farm management software, milk components, and milk FTIR output), regardless of prediction method (Pralle et al., 2018). Further improvement to model performance could be made by incorporating other data streams, such as rumination collars and accelerometers, which may provide additional insight into animal health and wellness; however, the inclusion of multiple data streams increases the technical difficulty for data alignment and quality control for the DHI and dairy producer. For the ultimate value of these tools to be achieved by the farm, the outcome of these models must also be returned in a timely manner from the time sampled. In the case of HYK, the ideal turnaround time from milk sampling to results being returned to the farm would be $24 \mathrm{~h}$, for cows to be treated. This challenge also extends far beyond monitoring HYK, or even general herd health, into whole-farm monitoring. Farms 
have countless data streams available to them. Many of these data sources are not discussed here but fall into attempts by industry and university collaborators to integrate into useful, proactive decision-making tools (Cabrera et al., 2020).

Model validation is of paramount importance in affirming the efficacy of any big data tools applied in practice. Most of the work in trait or outcome prediction relies on random cross-validation methods, where a random subset (or subsets) of data is excluded from model training and used for evaluation. Recently, Wang and Bovenhuis (2019) predicted cow methane emission from milk mid-infrared spectrum and demonstrated how this strategy can result in overoptimistic evaluation of model accuracy compared with block crossvalidation. Block cross-validation partitions data into training and evaluation data sets strategically by factors causing data dependence (e.g., farm); therefore, underestimated prediction error rates are avoided in data with systematic differences between blocks (Qin et al., 2016). In their study, Wang and Bovenhuis (2019) observed coefficients of determination of 0.49 and 0.01 in the validation sets for random cross-validation and block cross-validation, respectively. This is a massive difference that would mislead conclusions and potential application. With respect to HYK, this systematic confounding could occur due to previously alluded differences in diet composition and management practices altering basal concentrations of blood BHB or other milk characteristics. Furthermore, we believe this demonstrates the importance of collecting data from a diverse portfolio of herds and production systems for model training and validation.

Besides the progress made in using big data from onfarm data streams to improve cow health and disease management, omics technologies have provided big data mining opportunities for systems biologists to unravel the underlying mechanisms of physiological states (Loor et al., 2013). These applications interrogate the coordinated changes in biological processes and networks in a family of molecules, such as RNA (transcriptomics), proteins (proteomics), and molecules involved in cellular metabolism (metabolomics). Unlike reductionist approaches, omics techniques allow for unguided discovery of novel biological elements that can be incorporated into knowledge of the physiological state, such as metabolic disorders. For example, a microarray of the liver transcriptome from cows with nutrient-induced HYK highlighted the roles of transcription factors, protein ubiquitination, and inflammation, and suggested several novel genes (e.g., LPIN1, LPIN3, ANGPTL4) related to HYK etiology (Loor et al., 2007). Overall, this work is still in infancy, but it may augment our precision management strategies through greater ap- preciation of essential metabolic pathways, shifting toward a metabolic engineering approach.

\section{CONCLUSIONS}

The wealth of data available to dairy farms today presents immense opportunities. Substantial progress has been made in predicting HYK with management records, milk FTIR analysis, and genomics, which demonstrates the capacity of using a "big data" approach to derive practical solutions that can be implemented on farm. Moving forward, researchers will continue to push the capacity of big data to diagnose and perhaps predict future cases of health incidences. To effectively implement these tools for on-farm use, research and industry need to address the timeliness of data availability, the standardization of equipment measurements, and frameworks for data stream integration. Nonetheless, big data-oriented management strategies have great potential for improving animal health and productivity, ultimately improving dairy farm profitability through strategic management.

\section{ACKNOWLEDGMENTS}

The authors gratefully acknowledge the countless undergraduate and graduate students, farm and research staff, and collaborators who make our research contributions to this field possible. We recognize funding for the projects completed by the $\mathrm{H}$. M. White research group referenced here: USDA AFRI Critical Agriculture Research and Extension (CARE; 2015-6702823572); USDA Hatch (WIS01877 and WISC01878) from the Wisconsin Agricultural Experiment Station (Madison, WI); Cooperative Research Program for Agriculture Science and Technology Development (Project No. PJ012078) Rural Development Administration, Jeonju-si, Jeollabuk-do, Republic of Korea; AgSource Cooperative Services (research funding support and collaborative efforts; Verona, WI); Purina Animal Nutrition LLC (St. Louis, MO) graduate student fellowships; VitaPlus Corporation (Madison, WI) graduate student fellowship; and the Wisconsin Alumni Research Foundation (Madison, WI). Neither author has a conflict of interest.

\section{REFERENCES}

Andersson, L. 1984. Concentrations of blood and milk ketone bodies, blood isopropanol and plasma glucose in dairy cows in relation to the degree of hyperketonaemia and clinical signs. Zentralbl. Veterinarmed. A. 31:683-693. https://doi.org/10.1111/j.1439-0442.1984 .tb01327.x.

Blom, J. Y., J. M. Christensen, and C. Ridder. 2015. Real-time analyses of BHB in milk can monitor ketosis and its impact on reproduction in dairy cows. Pages 263-272 in Precision Livestock Farm- 
ing Applications. I. Halachmi, ed. Wageningen Academic Publishers, Wageningen, the Netherlands.

Cabrera, V., L. Fadul-Pacheco, J. Barrientos, and H. Delgado. 2020. Real-time continuous decision making using big data. J. Dairy Sci. https://doi.org/10.3168/jds.2019-17145.

Chandler, T. L., R. S. Pralle, J. R. R. Dórea, S. E. Poock, G. R. Oetzel, R. H. Fourdraine, and H. M. White. 2018. Predicting hyperketonemia by logistic and linear regression using test-day milk and performance variables in early-lactation Holstein and Jersey cows. J. Dairy Sci. 101:2476-2491.

Chandler, T. L., R. S. Pralle, G. R. Oetzel, R. H. Fourdraine, and H. M. White. 2015. Development of a ketosis prevalence detection tool in Holstein dairy cows based on milk component data and cow test-day information. J. Dairy Sci. 98 (Suppl. 3):507. (Abstr.)

de Roos, A. P. W., H. J. C. M. van den Bijgaart, J. Hørlyk, and G. de Jong. 2007. Screening for subclinical ketosis in dairy cattle by Fourier transform infrared spectrometry. J. Dairy Sci. 90:1761-1766. https://doi.org/10.3168/jds.2006-203.

DeFrain, J. M., A. R. Hippen, K. F. Kalscheur, and D. J. Schingoethe. 2006. Feeding lactose to increase ruminal butyrate and the metabolic status of transition dairy cows. J. Dairy Sci. 89:267-276. https://doi.org/10.3168/jds.S0022-0302(06)72091-4.

Denis-Robichaud, J., J. Dubuc, D. Lefebvre, and L. DesCôteaux. 2014. Accuracy of milk ketone bodies from flow-injection analysis for the diagnosis of hyperketonemia in dairy cows. J. Dairy Sci. 97:33643370. https://doi.org/10.3168/jds.2013-6744.

Enjalbert, F., M. C. Nicot, C. Bayourthe, and R. Moncoulon. 2001. Ketone bodies in milk and blood of dairy cows: Relationship between concentrations and utilization for detection of subclinical ketosis. J. Dairy Sci. 84:583-589. https://doi.org/10.3168/jds.S0022 -0302(01)74511-0.

Fourdraine, R. H., A. Samia Kalantari, J. Amdall, and A. D. Coburn. 2019. Using differential somatic cell count to improve udder health. ICAR Conference, Prague, Czech Republic. S12(T)-PP-05.

Grelet, C., C. Bastin, M. Gelé, J. B. Davière, M. Johan, A. Werner, R. Reding, J. A. Fernandez Pierna, F. G. Colinet, P. Dardenne, N. Gengler, H. Soyeurt, and F. Dehareng. 2016. Development of Fourier transform mid-infrared calibrations to predict acetone, $\beta$-hydroxybutyrate, and citrate contents in bovine milk through a European dairy network. J. Dairy Sci. 99:4816-4825. https://doi .org/10.3168/jds.2015-10477.

Ho, P. N., V. Bonfatti, T. D. W. Luke, and J. E. Pryce. 2019. Classifying the fertility of dairy cows using milk mid-infrared spectroscopy. J. Dairy Sci. 102:10460-10470. https://doi.org/10.3168/jds .2019-16412.

Iwersen, M., U. Falkenberg, R. Voigtsberger, D. Forderung, and W. Heuwieser. 2009. Evaluation of an electronic cowside test to detect subclinical ketosis in dairy cows. J. Dairy Sci. 92:2618-2624. https: //doi.org/10.3168/jds.2008-1795.

Jamrozik, J., A. Koeck, G. J. Kistemaker, and F. Miglior. 2016. Multiple-trait estimates of genetic parameters for metabolic disease traits, fertility disorders, and their predictors in Canadian Holsteins. J. Dairy Sci. 99:1990-1998. https://doi.org/10.3168/jds 2015-10505.

Kadarmideen, H., R. Thompson, and G. Simm. 2000. Linear and threshold model genetic parameters for disease, fertility and milk production in dairy cattle. Anim. Sci. 71:411-419. https://doi.org/ 10.1017/S1357729800055338.

Klein, S.-L., C. Scheper, K. Brügemann, H. H. Swalve, and S. König. 2019. Phenotypic relationships, genetic parameters, genome-wide associations, and identification of potential candidate genes for ketosis and fat-to-protein ratio in German Holstein cows. J. Dairy Sci. 102:6276-6287. https://doi.org/10.3168/jds.2019-16237.

Koeck, A., J. Jamrozik, F. S. Schenkel, R. K. Moore, D. M. Lefebvre, D. F. Kelton, and F. Miglior. 2014. Genetic analysis of milk $\beta$-hydroxybutyrate and its association with fat-to-protein ratio, body condition score, clinical ketosis, and displaced abomasum in early first lactation of Canadian Holsteins. J. Dairy Sci. 97:72867292. https://doi.org/10.3168/jds.2014-8405.

Lainé, A., C. Bastin, C. Grelet, H. Hammami, F. G. Colinet, L. M. Dale, A. Gillon, J. Vandenplas, F. Dehareng, and N. Gengler.
2017. Assessing the effect of pregnancy stage on milk composition of dairy cows using mid-infrared spectra. J. Dairy Sci. 100:28632876. https://doi.org/10.3168/jds.2016-11736.

Loor, J. J., M. Bionaz, and J. K. Drackley. 2013. Systems physiology in dairy cattle: Nutritional genomics and beyond. Annu. Rev. Anim. Biosci. 1:365-392. https://doi.org/10.1146/annurev-animal -031412-103728.

Loor, J. J., R. E. Everts, M. Bionaz, H. Dann, D. E. Morin, R. Oliveira, S. L. Rodriguez-Zas, J. K. Drackley, and H. A. Lewin. 2007. Nutrition-induced ketosis alters metabolic and signaling gene networks in liver of periparturient dairy cows. Physiol. Genomics 32:105-116. https://doi.org/10.1152/physiolgenomics.00188.2007.

Marstorp, P., T. Anfält, and L. Andersson. 1983. Determination of oxidized ketone bodies in milk by flow injection analysis. Anal. Chim. Acta 149:281-289. https://doi.org/10.1016/S0003-2670(00)83184 -0 .

McArt, J. A. A., D. V. Nydam, G. R. Oetzel, T. R. Overton, and P. A. Ospina. 2013. Elevated non-esterified fatty acids and $\beta$-hydroxybutyrate and their association with transition dairy cow performance. Vet. J. 198:560-570. https://doi.org/10.1016/j.tvjl .2013.08.011.

McArt, J. A. A., D. V. Nydam, and G. R. Oetzel. 2012a. A field trial on the effect of propylene glycol on displaced abomasum, removal from herd, and reproduction in fresh cows diagnosed with subclinical ketosis. J. Dairy Sci. 95:2505-2512. https://doi.org/10.3168/ jds.2011-4908.

McArt, J. A. A., D. V. Nydam, and G. R. Oetzel. 2012b. Epidemiology of subclinical ketosis in early lactation dairy cattle. J. Dairy Sci. 95:5056-5066. https://doi.org/10.3168/jds.2012-5443.

McArt, J. A. A., D. V. Nydam, G. R. Oetzel, and C. L. Guard. 2014. An economic analysis of hyperketonemia testing and propylene glycol treatment strategies in early lactation dairy cattle. Prev. Vet. Med. 117:170-179. https://doi.org/10.1016/j.prevetmed.2014 .06 .017 .

McParland, S., E. Kennedy, E. Lewis, S. G. Moore, B. McCarthy, M. O'Donovan, and D. P. Berry. 2015. Genetic parameters of dairy cow energy intake and body energy status predicted using midinfrared spectrometry of milk. J. Dairy Sci. 98:1310-1320. https:/ /doi.org/10.3168/jds.2014-8892.

Nani, J. P., F. M. Rezende, and F. Peñagaricano. 2019. Predicting male fertility in dairy cattle using markers with large effect and functional annotation data. BMC Genomics 20:258. https://doi .org/10.1186/s12864-019-5644-y.

Oetzel, G. R. 2004. Monitoring and testing dairy herds for metabolic disease. Vet. Clin. North Am. Food Anim. Pract. 20:651-674. https://doi.org/10.1016/j.cvfa.2004.06.006.

Overton, T. R., J. A. A. McArt, and D. V. Nydam. 2017. A 100-Year Review: Metabolic health indicators and management of dairy cattle. J. Dairy Sci. 100:10398-10417. https://doi.org/10.3168/jds 2017-13054.

Parker Gaddis, K. L., J. B. Cole, J. S. Clay, and C. Maltecca. 2014. Genomic selection for producer-recorded health event data in US dairy cattle. J. Dairy Sci. 97:3190-3199. https://doi.org/10.3168/ jds.2013-7543.

Parker Gaddis, K. L., J. H. Megonigal Jr., J. S. Clay, and C. W. Wolfe. 2018. Genome-wide association study for ketosis in US Jerseys using producer-recorded data. J. Dairy Sci. 101:413-424. https://doi .org/10.3168/jds.2017-13383.

Pralle, R. S., K. W. Weigel, N. E. Schultz, and H. M. White. 2019a. Hyperketonemia genome-wide association study in Holstein cows. Page 538 in Proc. European Association for Animal Production. (Abstr.) Wageningen Academic, Wageningen, the Netherlands.

Pralle, R. S., K. W. Weigel, N. E. Schultz, and H. M. White. 2019b. Hyperketonemia SNP by parity group genome-wide interaction study in Holstein cows. Page 541 in Proc. European Association for Animal Production. (Abstr.) Wageningen Academic, Wageningen, the Netherlands.

Pralle, R. S., K. W. Weigel, and H. M. White. 2018. Predicting blood $\beta$-hydroxybutyrate using milk Fourier transform infrared spectrum, milk composition, and producer-reported variables with multiple linear regression, partial least squares regression, and ar- 
tificial neural network. J. Dairy Sci. 101:4378-4387. https://doi .org/10.3168/jds.2017-14076.

Pryce, J. E., K. L. Parker Gaddis, A. Koeck, C. Bastin, M. Abdelsayed, N. Gengler, F. Miglior, B. Heringstad, C. Egger-Danner, K. F. Stock, A. J. Bradley, and J. B. Cole. 2016. Invited review: Opportunities for genetic improvement of metabolic diseases. J. Dairy Sci. 99:6855-6873. https://doi.org/10.3168/jds.2016-10854.

Qin, L.-X., H.-C. Huang, and C. B. Begg. 2016. Cautionary note on using cross-validation for molecular classification. J. Clin. Oncol. 34:3931-3938. https://doi.org/10.1200/JCO.2016.68.1031.

Ranaraja, U., K. Cho, M. Park, S. Kim, S. Lee, and C. Do. 2018. Genetic parameter estimation for milk $\beta$-hydroxybutyrate and acetone in early lactation and its association with fat to protein ratio and energy balance in Korean Holstein cattle. Asian-Australas. J. Anim. Sci. 31:798-803. https://doi.org/10.5713/ajas.17.0443.

Renaud, D. L., D. F. Kelton, and T. F. Duffield. 2019. Short communication: Validation of a test-day milk test for $\beta$-hydroxybutyrate for identifying cows with hyperketonemia. J. Dairy Sci. 102:15891593. https://doi.org/10.3168/jds.2018-14778.

Roche, J. R., J. K. Kay, C. V. C. Phyn, S. Meier, J. M. Lee, and C. R. Burke. 2010. Dietary structural to nonfiber carbohydrate concentration during the transition period in grazing dairy cows. J. Dairy Sci. 93:3671-3683. https://doi.org/10.3168/jds.2009-2868.

Sailer, K. J., R. S. Pralle, R. C. Oliveira, S. J. Erb, G. R. Oetzel, and H. M. White. 2018. Technical note: Validation of the BHBCheck blood $\beta$-hydroxybutyrate meter as a diagnostic tool for hyperketonemia in dairy cows. J. Dairy Sci. 101:1524-1529. https://doi.org/ $10.3168 /$ jds.2017-13583.

Šimundić, A. M. 2009. Measures of diagnostic accuracy: Basic definitions. EJIFCC 19:203-211.

Suthar, V. S., J. Canelas-Raposo, A. Deniz, and W. Heuwieser. 2013. Prevalence of subclinical ketosis and relationships with postpartum diseases in European dairy cows. J. Dairy Sci. 96:2925-2938. https://doi.org/10.3168/jds.2012-6035.

Tiplady, K. M., R. G. Sherlock, M. D. Littlejohn, J. E. Pryce, S. R. Davis, D. J. Garrick, R. J. Spelman, and B. L. Harris. 2019. Strategies for noise reduction and standardization of milk mid-infrared spectra from dairy cattle. J. Dairy Sci. 102:6357-6372. https://doi .org/10.3168/jds.2018-16144.

Toledo-Alvarado, H., A. I. Vazquez, G. de los Campos, R. J. Tempelman, G. Gabai, A. Cecchinato, and G. Bittante. 2018. Changes in milk characteristics and fatty acid profile during the estrous cycle in dairy cows. J. Dairy Sci. 101:9135-9153. https://doi.org/ $10.3168 /$ jds.2018-14480.

van der Drift, S. G. A., R. Jorritsma, J. T. Schonewille, H. M. Knijn, and J. A. Stegeman. 2012b. Routine detection of hyperketonemia in dairy cows using Fourier transform infrared spectroscopy analy- sis of $\beta$-hydroxybutyrate and acetone in milk in combination with test-day information. J. Dairy Sci. 95:4886-4898. https://doi.org/ 10.3168/jds.2011-4417.

van der Drift, S. G. A., K. J. E. van Hulzen, T. G. Teweldemedhn, R. Jorritsma, M. Nielen, and H. C. M. Heuven. 2012a. Genetic and nongenetic variation in plasma and milk $\beta$-hydroxybutyrate and milk acetone concentrations of early-lactation dairy cows. J. Dairy Sci. 95:6781-6787. https://doi.org/10.3168/jds.2012-5640.

van Knegsel, A. T. M., S. G. A. van der Drift, M. Horneman, A. P. W. de Roos, B. Kemp, and E. A. M. Graat. 2010. Short communication: Ketone body concentration in milk determined by Fourier transform infrared spectroscopy: Value for the detection of hyperketonemia in dairy cows. J. Dairy Sci. 93:3065-3069.

Vukasinovic, N., N. Bacciu, C. A. Przybyla, P. Boddhireddy, and S. K. DeNise. 2017. Development of genetic and genomic evaluation for wellness traits in US Holstein cows. J. Dairy Sci. 100:428-438. https://doi.org/10.3168/jds.2016-11520.

Wang, Q., and H. Bovenhuis. 2019. Validation strategy can result in an overoptimistic view of the ability of milk infrared spectra to predict methane emission of dairy cattle. J. Dairy Sci. 102:6288-6295. https://doi.org/10.3168/jds.2018-15684.

Wathes, C.M., H.H. Kristensen, J.-M. Aerts, and D. Berckmans. 2008. Is precision livestock farming an engineer's daydream or nightmare, an animal's friend or foe, and a farmer's panacea or pitfall? Comput. Electron. Agric. 64:2-10. https://doi.org/10.1016/ j.compag.2008.05.005.

Weigel, K. A., P. M. VanRaden, H. D. Norman, and H. Grosu. 2017. A 100-Year Review: Methods and impact of genetic selection in dairy cattle-From daughter-dam comparisons to deep learning algorithms. J. Dairy Sci. 100:10234-10250. https://doi.org/10.3168/ jds.2017-12954.

Wolfert, S., L. Ge, C. Verdouw, and M.-J. Bogaardt. 2017. Big data in smart farming - A review. Agric. Syst. 153:69-80. https://doi.org/ 10.1016/j.agsy.2017.01.023.

Zwald, N. R., K. A. Weigel, Y. M. Chang, R. D. Welper, and J. S. Clay. 2004. Genetic selection for health traits using producerrecorded data. I. Incidence rates, heritability estimates, and sire breeding values. J. Dairy Sci. 87:4287-4294. https://doi.org/10 .3168/jds.S0022-0302(04)73573-0.

\section{ORCIDS}

R. S. Pralle ำ https://orcid.org/0000-0001-9803-1152

H. M. White @ https://orcid.org/0000-0001-5449-2811 